\title{
IMPACT OF AGRICULTURAL EXPANSION AND URBANIZATION ON GROUNDWATER QUALITY USING SPATIAL ANALYSIS OF GIS AND REMOTE SENSING TECHNIQUES AT WADI EL-NATRUN AREA, EYGPT
}

\author{
El-Malky, M. ${ }^{(1)}$; Shalaby, A. ${ }^{(2)}$; Khalifa, A. ${ }^{(2)}$ and Gabreel, M. ${ }^{(3)}$
}

1) Institute of Environmental Studies and Research, Ain Sham University

2) National Authority for Remote Sensing and Space Sciences 3) Central Laboratory Department, Egyptian Mineral Recourses Authority

\begin{abstract}
Egypt faces a real water scarcity problem. Urban communities and agriculture in Egypt are clustered in the Nile Valley and Delta where water exists in abundance. Egyptian government has tended to encourage investors and farmers to establish agricultural and tourism projects in some desert areas. Wadi El-Natrun is area that suitable for agricultural expansion and tourism projects as it contains a good supply of groundwater. But Wadi ElNatrun is below sea level, this causes leak of contamination water to ground water by chemical fertilizers. At the same time an increasing amount of human wastes causes contamination of soil and surface water which move to groundwater aquifers and lead to contamination of groundwater. This study aim to assessing the quality of groundwater at Wadi El-Natrun in order to achieve sustainable development. Water samples have been collected from 28 random wells at the area of study where two samples were collected for each well during two different seasons, then physically analyzed including temperature and total dissolved solids and electrical conductivity and chemically analyzed including $\mathrm{PH}$, major cations Calcium $\left(\mathrm{Ca}^{2+}\right)$, Magnesium $\left(\mathrm{Mg}^{2+}\right)$, Sodium $\left(\mathrm{Na}^{+}\right)$, Potassium $\left(\mathrm{K}^{+}\right)$and major anions Bicarbonate $\left(\mathrm{HCO}^{-}\right)$, Carbonate $\left(\mathrm{CO}_{3}{ }^{2-}\right)$, Chloride $\left(\mathrm{Cl}^{-}\right)$and Sulphate $\left(\mathrm{SO}_{4}{ }^{2-}\right)$ as well as the trace elements ( $\mathrm{Fe}, \mathrm{Mn}, \mathrm{Cu}, \mathrm{Co}, \mathrm{Ni}, \mathrm{Cr}, \mathrm{Cd}, \mathrm{Pb}, \mathrm{As})$ and nutrients $\left(\mathrm{NH}_{4}{ }^{+}, \mathrm{NO}_{3}{ }^{-}, \mathrm{PO}_{4}{ }^{3-}\right)$. Geographic Information Systems (GIS) and remote sensing have been used for spatial analysis and mapping water quality. According to the chemical and Physical analysis, a lot of water wells


in Wadi EI-Natrun unsuitable for drinking and irrigation based on standards approved. From this study can concluded that Wadi El-Natrun have higher agriculture work and there are elevation in his communities and to achieve sustainable development must make temporary assessment to his ground water to stand each time to environmental impact for its ground water.

Key Words: Groundwater, Hydrochemistry, Wadi EI-Natrun, GIS, remote sensing, environmental pollution.

\section{INRODUCTION}

Environmental pollution has become a real danger at all the world, all components of the environment which lead to human survival as water, air, and food has become contaminated and that polluted is result of erroneous human behavior, the most important causes of water pollution in Egypt was the increased of population density around the Nile valley and its delta as well as the distribution a lot of slums in the big cities such as Cairo Alexandria in addition to some big cities in the Nile delta. Wadi EI-Natrun area is considered one of the important deserts areas in Egypt which the government has encouraged establishment of agricultural and construction project at it because it characterized by an abundance of groundwater but wells drilling have been done by random and uncontrolled system that lead to some problem at Wadi EI-Natrun groundwater as pollution and decrease in water level, (Fekry, 1993) has explained that in his study and indicated by Hydrogeological studies at the southern regions west of the Nile Delta that the lowering in groundwater heads south and east of Wadi EI-Natrun will be from $10 \mathrm{~m}$ to $15 \mathrm{~m}$ in the coming 50 years due to the rapid increase in the reclamation projects. In addition to the interface the ground water of Wadi EINatrun with the other surrounding water of different area which around the 
Wadi EI-Natrun, (Ahmed, 1999) explained that and indicate groundwater at the area of Wadi EI-Natrun and Sadat City which aquifer refer to the Pliocene aquifer may be mixed with waters of deeper aquifers by using isotope.

Many studies have been done on the Wadi El-Natrun but this different studies focused only on geological, geophysical, hydrological studies and few studies have low significance to environmental and hydrochemical properties of groundwater for making comparisons between the results of chemical and physical analysis of groundwater and making temporary identification to heavy metal of the same well at different climatic seasons this work focused to this. Gomma, 1995 classified the Pliocene aquifer into two water types (sodium-bicarbonate and sodium chloride). While Sharaky, et al., 2007 in their study concluded that the groundwater is slightly alkaline with concentrations of the major ions are higher than the maximum standard limits, according to the World Health Organization (WHO, 1996). The nutrient content of phosphate is also higher than the maximum standard values; while nitrate is in the critical level. Masoud, et al., 2011 they were recommended that Water levels and water quality show the need to improve water management in Wadi El-Natrun and adjacent areas. And the increase in groundwater abstraction from the Pliocene aquifer and other surrounding aquifers (Pleistocene and Miocene) has had some negative impacts on water levels and quality in some local areas in Wadi El-Natrun depression. 
J. Environ. Sci.

Institute of Environmental Studies and Research - Ain Shams University

\section{STUDY AREA}

1 OUTLINES AND LOCATION: The study area lies in the western area of the Nile delta in the north east region of the western desert of Egypt, Wadi El-Natrun depression lies at the western branch of the rood between Cairo and Alexandria approximately $110 \mathrm{~km}$ northwest of Cairo, or stretched between kilometer 78 to kilometer136 at the Cairo-Alexandria Desert Road and covers an area of about $281.7 \mathrm{Km}^{2}$ (i.e. 67608 feddans), . It extends between longitudes, $30^{\circ} 6^{\prime}$ and $30^{\circ} 30^{\prime} \mathrm{E}$ and latitudes, $30^{\circ} 16^{\prime}$ and $30^{\circ} 30^{\prime} \mathrm{N}$ Fig. (1).

2 CLIMAT: Wadi El-Natrun area is regarded as an extremely arid region. The climatic conditions of Wadi El-Natrun area are those characterizing the desert areas of Egypt, hot and long rainless summer The maximum temperature $\left(34.5^{\circ} \mathrm{C}\right)$ was recorded in July and August, while the minimum one $\left(7.5^{\circ} \mathrm{C}\right)$ was recorded in January with an average of $13.4{ }^{\circ} \mathrm{C}$ and $27.9{ }^{\circ} \mathrm{C}$ for the mean minimum and maximum annual temperature, respectively. The lowest value of evaporation $(1.8 \mathrm{~mm} /$ day $)$ was recorded during January, while the highest value $(7.9 \mathrm{~mm} /$ day $)$ was recorded in June. (After Meteorological Authority, 2006)

3 GEOMORGHOLOGICAL FEATURES: According to (Shata, 1962), (Shata et al., 1967), (Attia et al., 1970), (Omara and Sanad, 1975), (Abdel Baki, 1983), (Abu Zeid, 1984) Wadi El-Natrun depression future can be divided into three geomorphologic alluvial plains, structural Plains, and shifting sand drifts. 
4 GEOLOGICAL SETTING OF STUDY AREA: Many studies and researchers have been deals with the geology of the study area and the information is available in their works as (Said, 1962, Shata et al., 1962, La Moreaux, 1962, El-Fayoumy, 1964, El-Shazly et al., 1975, Attia et al., 1970, Omara and Sanad, 1975, Abdel Baki, 1983, Abu Zeid, 1984, Cherif et al., 2006, Ammar, 2010, Wassef, 2010) and others. Its include (Tertiary period) Deposits that appear on the surface of the study area were studied and classified as Pliocene deposits, Miocene deposits and Oligocene deposits then (Quaternary period). The Quaternary deposits include the Holocene age and the Pleistocene age. The Quaternary deposits that appear on the surface of the study area were studied and classified into the Holocene age which characterized by four rock units, sand dunes, sabkha deposits, alluvial gravel and undifferentiated Quaternary. The Pleistocene is characterized graded sand and gravel that intercalated by clay lenses.

5 HYDROGEOLOGY: Many authors reconsied three aquifer systems western Nile Delta e.g. delta aquifer (Quaternary), El Moghra aquifer (Miocene) and Wadi EI-Natrun Aquifer (Pliocene). In this research we focused at Wadi EINatrun Aquifer. Hydrology and hydrochemistry of study area was studied by many author as (Said, 1962, Shata et al., 1967, Pavlov, 1962, La-Moreaux, 1962, El-Fayoumy, 1967, El-Shazly et al., 1975, Attia, 1970, Omara and Sanad, 1975, Abdel Baki, 1983, Abu Zeid, 1984, Sadek et al., 2005, Cherif et al., 2006, Sharaky et al., 2007, Wassef, 2010, Ammar, 2010). Wadi El-Natrun aquifer is a local aquifer in the Pliocene beds that rests on top of Moghra Fm. The groundwater of the Pliocene aquifer varies from fresh to brackish water. The fresh water occurs in the southern and eastern portions of Wadi EI- 
Natrun. The thickness of this aquifer reaches to $140 \mathrm{~m}$ with a saturated thickness of $90 \mathrm{~m}$. The thickness decreases from east to west and southwards of Wadi EI-Natrun. (Sharaky et al., 2007)

\subsection{RECHARG AND DISCHARGE OF WATER: Recharge of} groundwater according to researches which have been done by (Abdel Baki, 1983, El-Maghraby, 1990, RIGW and IWACO, 1990, REGWA, 1993 and Dawoud et al., 2005) takes place due to its low level by seepage from the Nile stream the infiltration and downward leakage of excess irrigation water, infiltration of rainfall and inters aquifer flow of groundwater. And the main discharge takes place artificially through pumping of large number of production well sand or discharged through a great number of seepage zones into small lakes, ponds.

5.2 THE DEPTH OF WATER: According to (REGWA, 1993) and (RIGW, 1992). The fresh water thickness ranges from 15 to $25 \mathrm{~m}$. In the other hand the depth to water different according to topography of Wadi El-Natrun at the south of the Wadi EI-Natrun Depression where the depth to groundwater increases due to the high topography in this areas, from $40 \mathrm{~m}$ up to about 150 $\mathrm{m}$ at the Southeast and up to about $190 \mathrm{~m}$ at the Southwest (RIGW, 1992).

\subsection{OVERLAP HYDROLOGICAL SYSTEMS AT THE STUDY AREA:} Previous studies (Abdel Baki, 1983, RIGW and IWACO, 1990, Sharaky, et al., 2007) have confirmed that there is an overlap in the water system in the study area and water systems around the area of study. 


\section{FIELD TRIPS AND SAMPLES COLLECTION}

Ground water samples were collected from different random 28 wells with Record some field observations and making a questionnaire about the quality of water by population and village communities in the study area in two liter clean and free of contaminants polyethylene bottles, after taking every groundwater samples from the well put it directly to iceboxes contain ice to cooled it at $4^{\circ} \mathrm{C}$ to prevent the changing in the composition of water as possible sample identification by Sample number, location, date and hour, well deep, water temperature at the studied area, the selected wells are used for drinking, irrigation and domestic use the wells have depths varying from 65 to $125 \mathrm{~m}$ collected two samples per well over two years. The first sampling trip between 15 to 21 during July 2015.The second sampling trip between 10 to17 during May 2016.the coordination of the 28 studied wells were detected by using a handheld GPS instrument GARMIN GPS 12 CX points of samples is shown in Fig. (1), Water Temperature $\left(\mathrm{T}^{\circ} \mathrm{C}\right)$ detected during field trip at the sampling sites by mercury in glass thermometer from (0 to 100) degrees selezaos $\left({ }^{0} \mathrm{C}\right)$. The samples were acidified to $\mathrm{pH} 1.5-2.0$ using concentrated $\mathrm{HNO}_{3}$ for analysis of metals. Analyze of water samples done quickly as possible after arrived it at the laboratory within twenty-four hours of collection. 


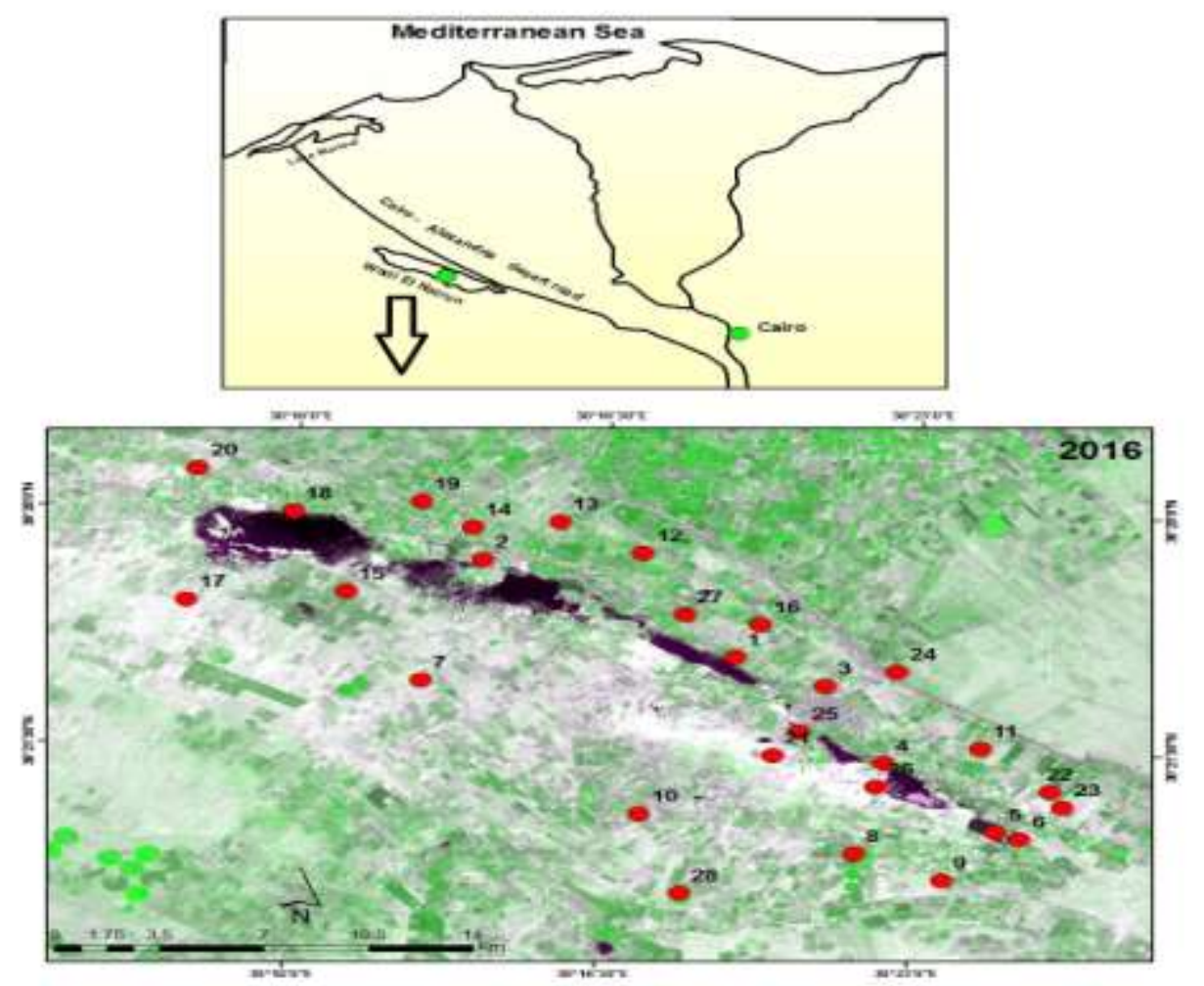

Fig. 1: Location map of the study area red circles represent studied 28 Water wells in Wadi El-Natrun.

\section{CHANGE DETECTION IN THE STUDY AREA}

Changes in study area during thirty years ago were detected by digital image enhancement and classification techniques were applied to Landsat 5 TM imageries acquired on 1984 and Centennial two acquired on 2016 respectively. Land cover classes by supervised classification implemented in ENVI 5.1 and Arc GIS 10.1 and land cover maps were produced. Results 
Fig.(2) Showed extensive reclamation practices to the north and south of Wadi El-Natrun and there are new urban communities.
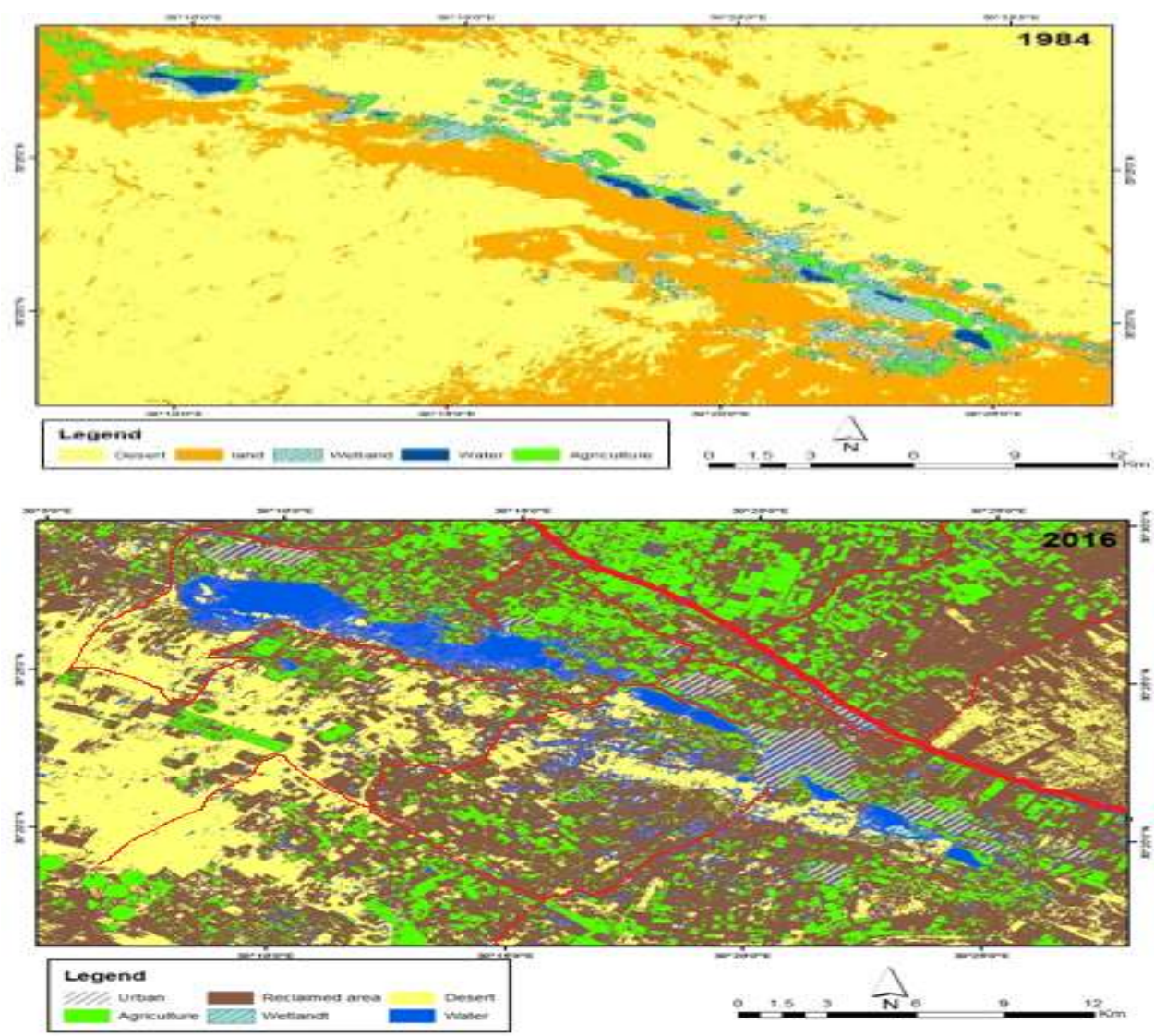

Fig. 2: Land change maps of Wadi El-Natrun area during 1984 to 2016

\section{PHSICO-CHEMICAL ANALYSIS OF WATER SAMPLES}

The analyzing processes had been done in water and air lab. in the central laboratory of Egyptian Mineral Authority and Mining Projects (EMRA) with assistance of the staff of the laboratory following the (Standard Methods for the Examination of Water and 
Wastewater; APHA, AWWA, and WEF, $21^{\text {st }}$ Edition, 2005) which include Physical parameter of water samples including Electrical Conductivity (EC) which was measured by an electric conductivity meter model YSI 33, U.S. with an Accuracy of $\pm 1 \%$ and (TDS) total dissolved solid by evaporated and dryness at $180^{\circ} \mathrm{C}$. Chemical parameters of water samples including $\mathrm{pH}$ which measured by using a laboratory $\mathrm{pH}$ meter model MP230 German with an accuracy of $\pm 1 \%$. Major cations Calcium $\left(\mathrm{Ca}^{2+}\right)$ and Magnesium $\left(\mathrm{Mg}^{2+}\right)$ and major anions Bicarbonate $\left(\mathrm{HCO}^{-}\right)$, Carbonate $\left(\mathrm{CO}_{3}{ }^{2-}\right)$ and Chloride $\left(\mathrm{Cl}^{-}\right)$ were detected by volumetric. Sodium $\left(\mathrm{Na}^{+}\right)$and Potassium $\left(\mathrm{K}^{+}\right)$were detected by using atomic absorption (thermo fisher scientific) model ICE 3000 SERIS. Sulphate $\left(\mathrm{SO}_{4}{ }^{2-}\right)$ was determined by turbid metric were done by using Spectrophotometer model UV-160A UVVisible Recording spectrophotometer shimadzu. Nutrients $\left(\mathrm{NH}_{4}^{+}\right.$, $\mathrm{NO}_{3}{ }^{-}, \mathrm{PO}_{4}{ }^{3-}, \mathrm{NH}_{4}{ }^{+}$) was analyzed using ammonia selective electrode model ISE Digital DM-21, $\mathrm{NO}_{3}{ }^{-}$by using spectrophotometer as well as the trace elements ( $\mathrm{Fe}, \mathrm{Mn}, \mathrm{Cu}, \mathrm{Cd}, \mathrm{Ni}, \mathrm{Co}, \mathrm{Pb}, \mathrm{Cr}, \mathrm{As}$ ) by using I.C.P Inductive Coupling Plasma Agilent 720.

\section{WATER QUALITY MAPS:}

The wells locations were integrated with the results of water parameter for the generation of spatial distribution maps of selected water quality using the basic geo-database creation function of Arc GIS 10.1 software. The present study used the Inverse Distance Weighted (IDW) method for spatial interpolation of water pollutants or other parameters Fig. $(3,4,5,6)$. This 
method used a defined or selected set of sample points for estimating the output grid cell value. It determines the cell values using a linearly weighted combination of a set of sample points and controls the significance of known points upon the interpolated values based upon their distance from the output point thereby generating a surface grid as well as thematic isolines. (Shomar, et. al., 2010).

\section{RESULTES AND DISCUSSION}

The physical and chemical parameters of the analytical results of groundwater were compared with the standard guideline values recommended for drinking and public health purposes as (WHO, 2006) and other.

1 PHYSICAL PARAMETERS: All water samples appeared colorless and odorless the temperatures of ground water samples varied from $17.5-22^{\circ} \mathrm{C}$ which suggested that all water samples are suitable for plant growth because at temperature more than $30^{\circ} \mathrm{C}$ delay and decay the plant growth (Lawson, 2011). Table(1) show the (TDS) of water samples Based on the classification of (Robinove et al., 1958) were $32 \%$ of the wells classified as moderately saline and $100 \%$ of the wells out of permissible limits of TDS in drinking water $1000 \mathrm{mg} / \mathrm{L}$ (WHO,2006 and 2004). Table (2) show the $\mathrm{pH}$ of water samples were all wells under study have base $\mathrm{pH}$ value and all Welles have the permissible $\mathrm{pH}$ range. The permissible $\mathrm{pH}$ range for drinking varies between 6.5 and 8.5 (WHO, 2006). 
Table (1): Wells class according to TDS (Robinove et al., 1958) classification

\begin{tabular}{|c|c|c|}
\hline TDS Value & Remark on Class & Wells class \\
\hline \hline \multirow{2}{*}{$1000-3000$} & Fresh water & $\begin{array}{c}3,4,6,7,8,9,10,11,13,14,15,18,20,21,22 \\
23,24,25,28\end{array}$ \\
& & $1,2,5,12,16,17,19,26,27$ \\
\hline $3000-10,000$ & Moderately saline & 0 \\
\hline $10,000-35,000$ & Very saline & 0 \\
\hline$>35,000$ & Briny & \\
\hline
\end{tabular}

Table (2): Wells class according to $\mathrm{pH}$ Value (WHO, 2006).

\begin{tabular}{|c|c|c|}
\hline pH Value & Remark on Class & Wells class \\
\hline \hline $0<\mathrm{pH}<7.0$ & Acidic & 0 \\
\hline $\mathrm{pH}=7$ & Neutral & 0 \\
\hline $7<\mathrm{pH} \leq 14$ & Alkaline & $\begin{array}{c}1,2,3,4,5,6,7,8,9,10,11,12,13,14,15,16,17 \\
18,19,20,21,22,23,24,25,26,27,28 .\end{array}$ \\
\hline
\end{tabular}

Water capability to transmit electric current is known as electrical conductivity and serves as tool to assess the purity of water (Murugesan et. al., 2006) water samples during July 2015 and May 2016 most of the wells under study have EC greater than normal range for water $400-600 \mu \mathrm{S} / \mathrm{cm}$ (WHO, 2006). Which the permissible limits for drinking water Fig. (3), represents Spatial Distribution Maps of Groundwater Quality for physical Paramete

2 MAJOR CATIONS: The maximum and minimum concentration of major cations in the groundwater is shown in Table (3). Which presented the results during May 2015 and July 2016. $\mathrm{Na}^{+}$concentration exceeded the permissible limits in drinking water $200 \mathrm{mg} / \mathrm{L}$ (WHO, 2006), Thus $100 \%$ of the wells under study exceeded the permissible limits of the drinking 
water, $\mathrm{K}^{+}$concentration exceeded the permissible limits of the drinking water $12 \mathrm{mg} / \mathrm{L}$ (WHO, 2006) thus about $72 \%$ of wells under study out of permissible rang of drinking water, $\mathrm{Ca}^{2+}$ concentration recorded normal ratio less than the highest rate permitted $75 \mathrm{mg} / \mathrm{L}$ (WHO, 2006) except wells number $(1,2,12)$ have high value, $\mathrm{Mg}^{2+}$ concentration as seen in table 3 which $90 \%$ of the wells have the normal value $30-50 \mathrm{mg} / \mathrm{l}$ (WHO, 2006) expect wells number $(12,16,23)$ during May 2015 increase than normal value but during July 2016 its down to normal value . Fig. (4), represents Spatial Distribution Map of Groundwater Quality Cations Parameters.

Table (3): Wells class according to concentration of major cations

\begin{tabular}{|c|c|c|c|c|c|c|}
\hline \multirow{2}{*}{ Cations } & \multicolumn{2}{|c|}{$\begin{array}{c}\text { Minimum, mg/L } \\
\text { During }\end{array}$} & \multicolumn{2}{|c|}{$\begin{array}{l}\text { Maximum, } \\
\text { mg/L During }\end{array}$} & \multicolumn{2}{|c|}{$\begin{array}{c}\text { Average value, } \\
\mathrm{mg} / \mathrm{L}\end{array}$} \\
\hline & $\begin{array}{l}\text { May } \\
2015 \\
\end{array}$ & $\begin{array}{l}\text { July } \\
2016 \\
\end{array}$ & $\begin{array}{l}\text { May } \\
2015\end{array}$ & $\begin{array}{l}\text { July } \\
2016\end{array}$ & $\begin{array}{l}\text { May } \\
2015 \\
\end{array}$ & $\begin{array}{l}\text { July } \\
2016 \\
\end{array}$ \\
\hline Sodium $\mathrm{Na}^{+}$ & 256.4 & 175 & 2035 & 1997 & 7712.1 & 645 \\
\hline Potassium $\mathrm{K}^{+}$ & 5.2 & 5.72 & 67 & 63 & 18.77 & 18.26 \\
\hline Calcium $\mathrm{Ca}^{2+}$ & 18.2 & 17.4 & 372 & 302 & 93.24 & 83.61 \\
\hline MagnesiumMg $^{2+}$ & 14.3 & 11.31 & 261 & 255 & 72.28 & 65.38 \\
\hline
\end{tabular}

3 MAJOR ANIONS: The maximum and minimum concentration of major anions in the groundwater is shown in Table (4). Which presented the May 2015 and July 2016. $\left(\mathrm{Cl}^{-}\right)$concentration results indicated that $93 \%$ of the wells out of permissible rang of drinking water $250 \mathrm{mg} / \mathrm{L}$ (WHO, 2004 and 2006) expect wells $(20,21),\left(\mathrm{SO}_{4}{ }^{2-}\right)$ concentration indicated that $75 \%$ of the wells out of permissible rang of drinking water $250 \mathrm{mg} / \mathrm{L}(\mathrm{WHO}$, 2004 and 2006). ( $\mathrm{HCO}^{-}$) concentration indicated that $64 \%$ of the wells have the permissible limits of drinking water $250 \mathrm{mg} / \mathrm{L}$ (WHO, 2004 and, 
2006) expect well 5 which record very high value is not suitable for irrigation. Fig. (5), represents Spatial Distribution Map of Groundwater Quality Anions Parameters.

Table (4): Wells class according to concentration of major anions.

\begin{tabular}{|l|c|c|c|c|c|c|}
\hline \multirow{2}{*}{ Conc. } & \multicolumn{2}{|c|}{$\begin{array}{c}\text { Minimum, } \\
\text { mg/L During }\end{array}$} & \multicolumn{2}{c|}{$\begin{array}{c}\text { Maximum, } \\
\text { mg/L During }\end{array}$} & \multicolumn{2}{c|}{$\begin{array}{c}\text { Average value, } \\
\text { mg/L }\end{array}$} \\
\cline { 2 - 8 } & $\begin{array}{c}\text { May } \\
\mathbf{2 0 1 5}\end{array}$ & $\begin{array}{c}\text { July } \\
\mathbf{2 0 1 6}\end{array}$ & $\begin{array}{c}\text { May } \\
\mathbf{2 0 1 5}\end{array}$ & $\begin{array}{c}\text { July } \\
\mathbf{2 0 1 6}\end{array}$ & $\begin{array}{c}\text { May } \\
\mathbf{2 0 1 5}\end{array}$ & $\begin{array}{c}\text { July } \\
\mathbf{2 0 1 6}\end{array}$ \\
\hline Carbonate $\mathrm{CO}_{3}{ }^{2-}$ & 9.6 & 7.5 & 360 & 309 & 31.05 & 26.96 \\
\hline Bicarbonate $\mathrm{HCO}^{-}$ & 131.7 & 101.3 & 1707 & 1402 & 280.5 & 264.8 \\
\hline Chloride $\mathrm{Cl}^{-}$ & 207 & 202 & 2651 & 2607 & 917.2 & 851.3 \\
\hline Sulphate $\mathrm{SO}_{4}{ }^{2-}$ & 95 & 78.2 & 1980 & 1670 & 553.5 & 488.8 \\
\hline
\end{tabular}

4 NUTRIENTS: The maximum and minimum concentration of Nutrients in the groundwater is shown in Table (5). Which presented the results during May 2015 and July 2016. Concentration of $\left(\mathrm{NO}_{3}{ }^{-}\right)$for 53\% of wells is higher than the acceptable concentration in drinking water $10 \mathrm{mg} / \mathrm{L}$ (USEPA, 2005, Vogel, 1961) well 9 recorded slightly higher e acceptable value for irrigation water ( $23 \mathrm{mg} / \mathrm{L}$; FAO, 1985 )where $100 \%$ of the wells recorded value higher than the permissible value for $\left(\mathrm{NH}_{4}{ }^{+}\right)$concentration $0.5 \mathrm{mg} / \mathrm{L}$; (WHO, 1998) Expect well number 1 and $\left(\mathrm{PO}_{4}{ }^{3-}\right)$ concentration0.1 mg/L; (WHO, 1998) this is elevation due to extensive use of fertilizer due more expansion in agriculture work. 
Table (5): Wells class according to concentration of Nutrients.

\begin{tabular}{|l|c|c|c|c|c|c|}
\hline \multirow{2}{*}{ Conc. } & \multicolumn{2}{|c|}{$\begin{array}{c}\text { Minimum, mg/L } \\
\text { During }\end{array}$} & \multicolumn{2}{c|}{$\begin{array}{c}\text { Maximum, mg/L } \\
\text { During }\end{array}$} & \multicolumn{2}{c|}{$\begin{array}{c}\text { Average value, } \\
\text { mg/L }\end{array}$} \\
\cline { 2 - 7 } & $\begin{array}{c}\text { May } \\
\mathbf{2 0 1 5}\end{array}$ & $\begin{array}{c}\text { July } \\
\mathbf{2 0 1 6}\end{array}$ & $\begin{array}{c}\text { May } \\
\mathbf{2 0 1 5}\end{array}$ & $\begin{array}{c}\text { July } \\
\mathbf{2 0 1 6}\end{array}$ & $\begin{array}{c}\text { May } \\
\mathbf{2 0 1 5}\end{array}$ & $\begin{array}{c}\text { July } \\
\mathbf{2 0 1 6}\end{array}$ \\
\hline Nitrates, $\mathrm{NO}_{3}{ }^{-}$ & 0.14 & 0.32 & 24 & 21.23 & 9.783 & 7.516 \\
\hline Ammonia, $\mathrm{NH}_{4}{ }^{+}$ & 0.6 & 0.2 & 5.7 & 5.6 & 3.069 & 2.539 \\
\hline Phosphate, $\mathrm{PO}_{4}{ }^{2-}$ & 0.7 & 0.8 & 3 & 3 & 2.107 & 1.916 \\
\hline
\end{tabular}

5 TRACE ELEMENTS (HEAVY METALS): The maximum and minimum concentration of trace elements in the groundwater is shown in Table (6) .which presented the results during May 2015 and July 2016. (Fe) less than permissible limits $0.3 \mathrm{mg} / \mathrm{L}$ (WHO 2006 and 2011), manganese less than permissible limits, $(\mathrm{Ni}),(\mathrm{Cd}),(\mathrm{As})$ and $(\mathrm{Cr})$ not detected in $100 \%$ of the wells under study, $(\mathrm{Cu})$ not increase than the permissible limits $1 \mathrm{mg} / \mathrm{L}$ (Gray, 2005), (Pb) concentration in all wells under study not increase than permissible limits $0.01 \mathrm{mg} / \mathrm{L}$ (WHO, 2006 and 2011). 
Table (6): Concentration of Heavy metals.

\begin{tabular}{|l|c|c|c|c|c|c|c||}
\hline \multirow{3}{*}{ Nutrients } & \multicolumn{2}{|c|}{$\begin{array}{c}\text { Minimum, } \\
\text { mg/L During }\end{array}$} & \multicolumn{2}{c|}{$\begin{array}{c}\text { Maximum, } \\
\text { mg/L During }\end{array}$} & \multicolumn{2}{c|}{$\begin{array}{c}\text { Average } \\
\text { value, mg/L }\end{array}$} & $\begin{array}{c}\text { Drinkin } \\
\text { g water } \\
\text { mg/L }\end{array}$ \\
\cline { 2 - 8 } & $\begin{array}{c}\text { May } \\
\mathbf{2 0 1 5}\end{array}$ & $\begin{array}{c}\text { July } \\
\mathbf{2 0 1 6}\end{array}$ & $\begin{array}{c}\text { May } \\
\mathbf{2 0 1 5}\end{array}$ & $\begin{array}{c}\text { July } \\
\mathbf{2 0 1 6}\end{array}$ & $\begin{array}{c}\text { May } \\
\mathbf{2 0 1 5}\end{array}$ & $\begin{array}{c}\text { July } \\
\mathbf{2 0 1 6}\end{array}$ & \\
\hline Iron, Fe & 0.03 & 0.03 & 0.36 & 0.09 & 0.156 & 0.075 & 1.0 \\
\hline Manganese Mn & 0.07 & 0.04 & 0.13 & 0.11 & 0.095 & 0.073 & 0.05 \\
\hline Nickel Ni & N.D & N.D & N.D & N.D & N.D & N.D & 0.02 \\
\hline Cadmium Cd & N.D & N.D & N.D & N.D & N.D & N.D & 0.003 \\
\hline Cupper Cu & 0.05 & 0.02 & 0.17 & 0.09 & 0.127 & 0.045 & 1 \\
\hline Lead Pb & 0.001 & 0.001 & 0.004 & 0.005 & 0.002 & 0.002 & 0.01 \\
\hline Chromium Cr & N.D & N.D & N.D & N.D & N.D & N.D & 0.05 \\
\hline Cobalt Co & N.D & N.D & N.D & N.D & N.D & N.D & 0.04 \\
\hline Arsenic As & N.D & N.D & N.D & N.D & N.D & N.D & 0.01 \\
\hline
\end{tabular}

6 DETECTION THE QUALITY OF WATER FOR IRRIGATION: In addition to major cations and anions there are other parameter used to determine the quality of water for irrigation for example, SAR, RSC, \% Na, \%Mg. Fig.(6), represents Spatial Distribution Map of Groundwater Quality for irrigation Parameters.

6.1 THE SODIUM ADSORPTION RATIO (SAR): SAR is the better measure of the sodium hazard for irrigation, According to the (US salinity laboratory, 1954) Sodium Adsorption Ratio (SAR) measures the relative concentration of sodium to calcium and Magnesium. High sodium ions in water affect the permeability of soil and causes infiltration problems. SAR expressed in milli equivalents/liter (meq/L). SAR $=\mathrm{Na}^{+} \backslash\left(\mathrm{Ca}^{+2}+\mathrm{Mg}^{+2} \backslash\right.$ $2)^{112}$ 
Table (7): Wells class according to SAR Ratio.

\begin{tabular}{|c|l|l|}
\hline SAR ratio & Remark on quality & \multicolumn{1}{c|}{ Wells class for irrigation } \\
\hline \hline $0<\mathrm{SAR}<10$ & Excellent & $3,4,8,10,14,20,22,23,24$. \\
\hline $10<\mathrm{SAR}<18$ & Good & $1,2,6,7,9,11,12,13,15,17,18,21,25,28$. \\
\hline $18<\mathrm{SAR}<26$ & Doubtful & $16,19,27$. \\
\hline SAR $>26$ & Unsuitable & $5,26$. \\
\hline
\end{tabular}

6.2 PRECENT SODIUM (\% Na): (Todd, 2006) reported that Sodium concentration is important in classifying irrigation water because sodium reacts to soil to reduce its permeability. Sodium content is usually expressed in terms of percent sodium also known as soluble sodium percentage, $\% \mathrm{Na}$ expressed in milli equivalents/liter. $\mathrm{Na} \%=\left(\mathrm{Na}^{+}+\mathrm{K}^{+}\right)$ $\times 100 /\left(\mathrm{Na}^{+}+\mathrm{K}^{+}+\mathrm{Mg}^{+2}+\mathrm{Ca}^{+2}\right)$.

Table (8): Wells class according to $\% \mathrm{Na}$ value.

\begin{tabular}{|c|c|c|}
\hline$\% \mathbf{N a}$ & Remark on quality & Wells class for irrigation \\
\hline \hline$\% \mathrm{Na}<20$ & Excellent & 0 \\
\hline $20<\% \mathrm{Na}<40$ & Good & 0 \\
\hline $40<\% \mathrm{Na}<60$ & permissible & 23 \\
\hline $60<\% \mathrm{Na}<80$ & Doubtful & $1,2,3,4,6,7,9,10,12,13,14,15,16,20,22,24$ \\
\hline$\% \mathrm{Na}>80$ & Unsuitable & $5,8,11,18,19,21,25,26,27,28$. \\
\hline
\end{tabular}

6.3 RESIDUAL SODIUM CARBONATE (RSC): When water having high concentration of carbonate and bicarbonate that lead increase the tendency for $\mathrm{Mg}^{2+}, \mathrm{Ca}^{2+}$ to precipitate and the relative proportion of sodium in the water is increased in the form of sodium carbonate RSC calculated and expressed in milli equivalents/liter as Hagen , (1987) told. $\mathrm{RSC}=\left(\mathrm{HCO}^{-}+\right.$ $\left.\mathrm{CO}_{3}{ }^{2-}\right)-\left(\mathrm{Ca}^{2+}+\mathrm{Mg}^{2+}\right)$ 
Table (9): Wells class according to RSC value.

\begin{tabular}{|c|c|c|}
\hline RSC ratio & Remark on quality & Wells class for irrigation \\
\hline \hline RSC $<1.25$ & Good & $\begin{array}{c}1,2,3,4,7,9,10,12,13,14,15,16,17, \\
18,19,20,22,23,24,26,27 .\end{array}$ \\
\hline $1.25<\mathrm{RSC}<2.5$ & Doubtful & $6,8,11,21,25,28$ \\
\hline $\mathrm{RSC}>2.5$ & Unsuitable & $16,19,27$. \\
\hline
\end{tabular}

6.4 PERECENT MAGNESIUM (\%Mg): When the concentration of magnesium increases in irrigation water lead to become hazard for plants percent of magnesium expressed by (Szabolcs et al., 1964). \% Mg should be not more than 50\%. $\mathrm{Mg} \%$ expressed in milli equivalents/liter. $\mathrm{Mg} \%=$ $(\mathrm{Mg} / \mathrm{Mg}+\mathrm{Ca}) \times 100$

Table (10): Wells class according to \% Na values.

\begin{tabular}{|c|c|c|}
\hline \hline $\boldsymbol{M g}$ & Remark on quality & Wells class for irrigation \\
\hline \hline$\% M g<50$ & Excellent & $1,2,3,4,6,8,13,14,20,24$ \\
\hline \multirow{2}{*}{$\% g g 50$} & \multirow{2}{*}{ Hazard } & $5,7,9,10,11,12,15,16,17$ \\
& \multicolumn{2}{|c|}{} \\
\hline
\end{tabular}




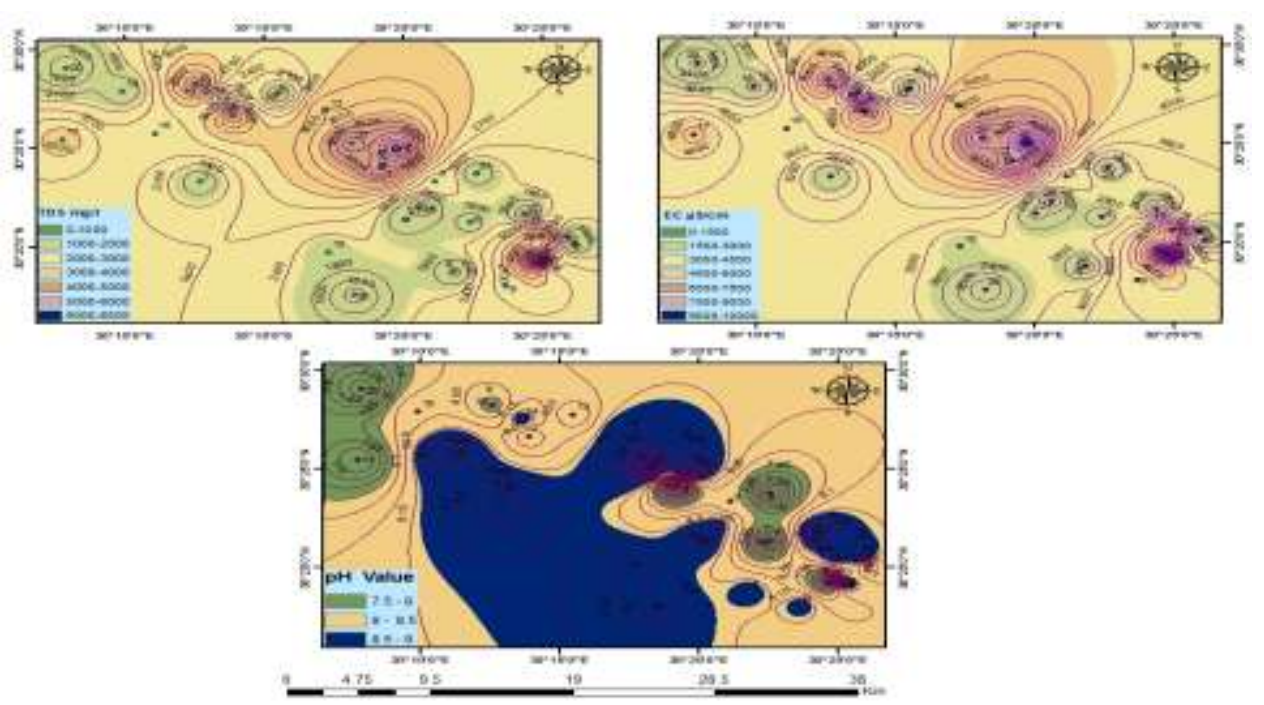

Fig. (3): Spatial Distribution Map of Groundwater physical Parameters.
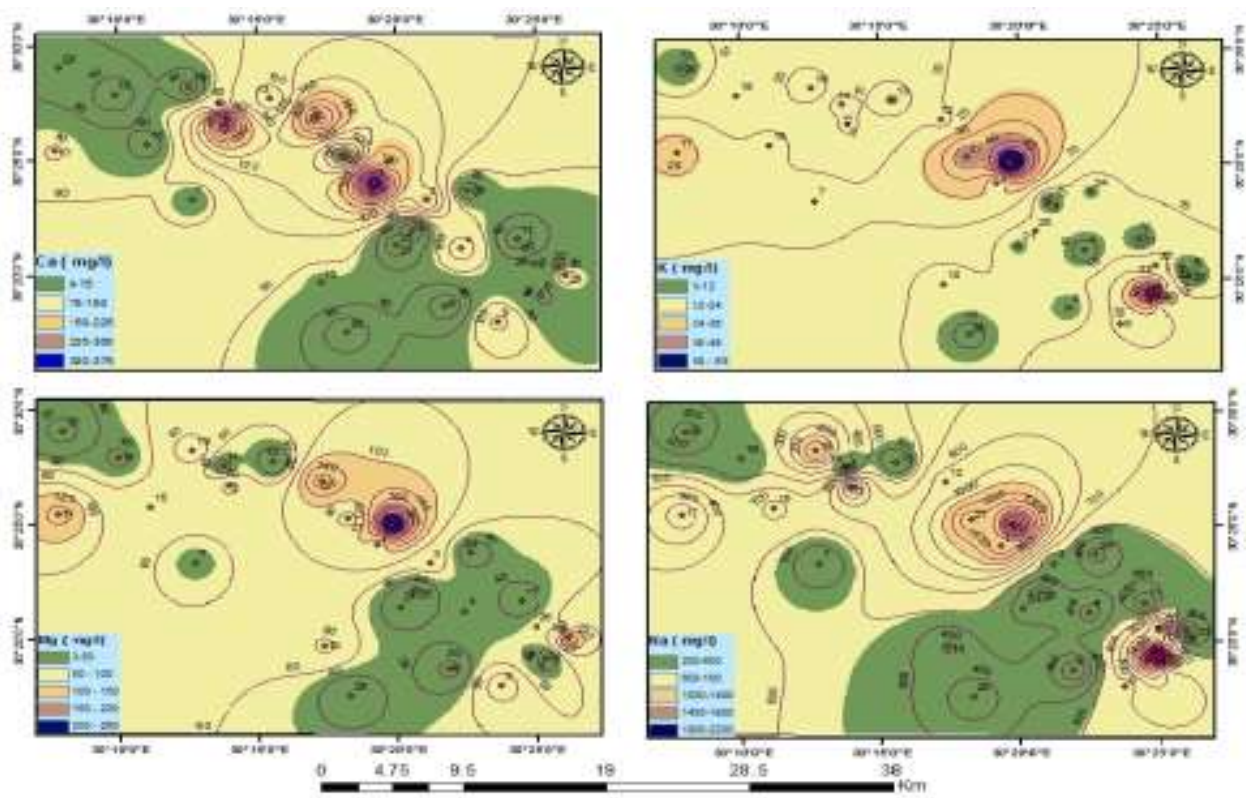

Fig. (4): Spatial Distribution Map of Groundwater Cations Parameters.

Vol. 40, No.1, Dec. 2017 
J. Environ. Sci.

Institute of Environmental Studies and Research - Ain Shams University
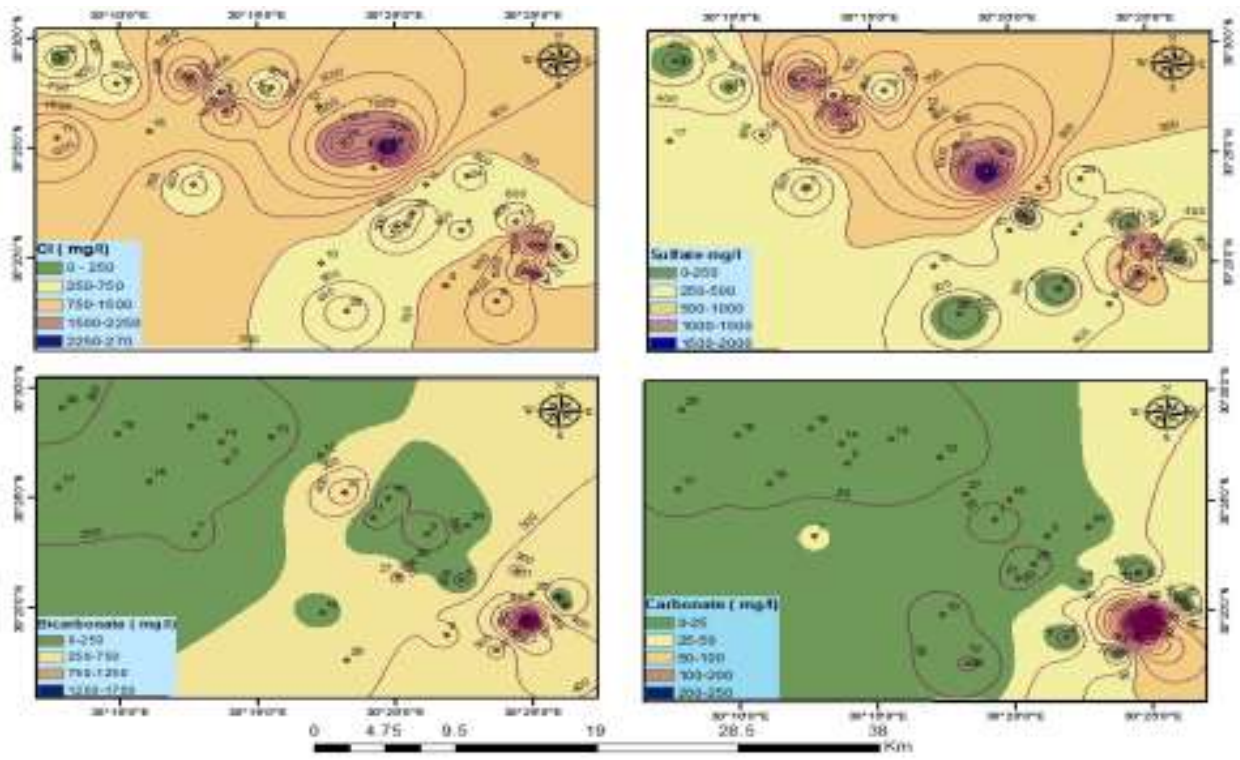

Fig. (5): Spatial Distribution Map of Groundwater Anions Parameter.
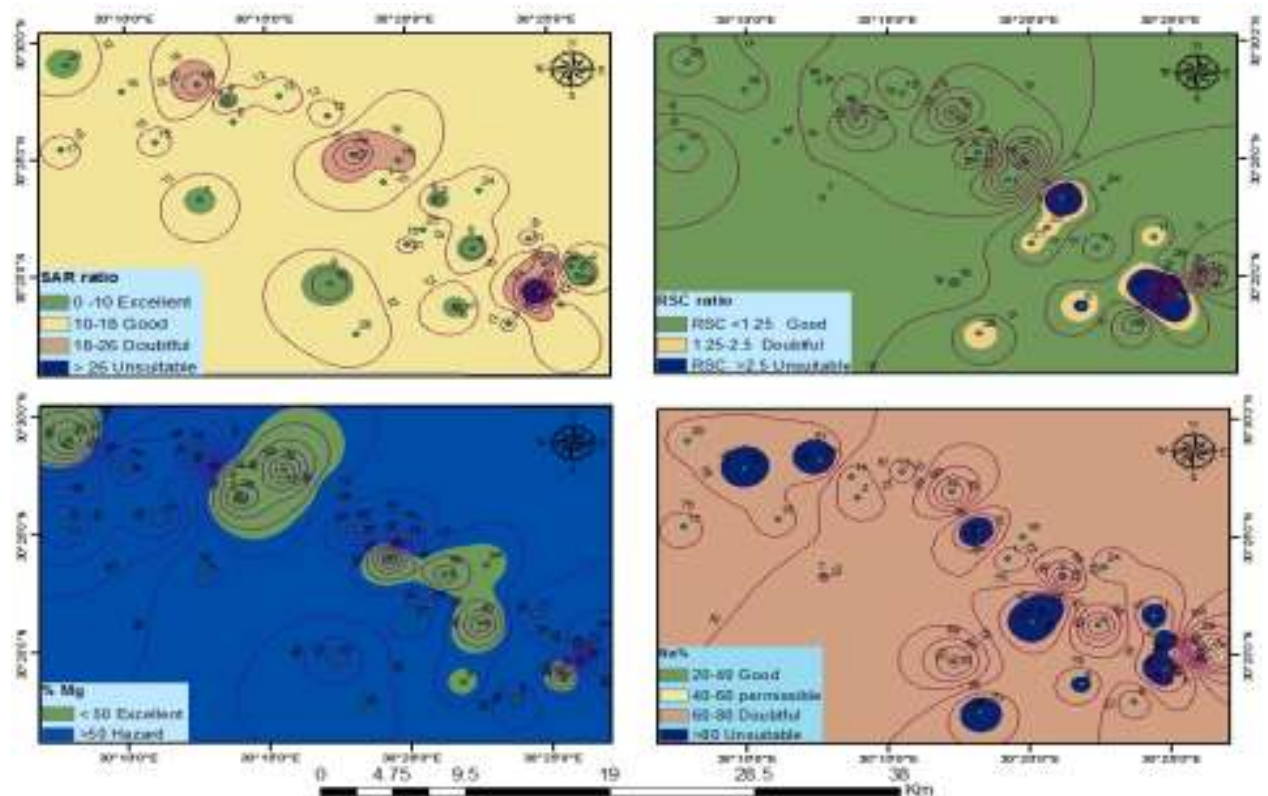

Fig. (6): Spatial Distribution Map of Groundwater for irrigation Parameters. 


\section{CONCLUSION AND RECOMMENDATION}

According to the physico-chemical parameters that obtained from analysis of 28 wells which located in Wadi El-Natrun area it was concluded that water of this wells have range of $\mathrm{pH}$ suitable for drinking purpose samples ranges from 7.5-8.5. 32\% of Sample moderately saline, Sodium and potassium concentration in groundwater found higher the permissible limit of (WHO). $\mathrm{Ca}^{2+}$ within normal ratio except wells number $(1,2,12)$ while $\mathrm{Mg}^{2+}$ are found suitable for drinking expect wells number $(12,16,23) .\left(\mathrm{Cl}^{-}\right)$ concentration indicated that $93 \%$ of the wells out of permissible expect wells $(20,21),\left(\mathrm{SO}_{4}{ }^{2-}\right)$ concentration indicated that $75 \%$ of the wells out of permissible rang $\left(\mathrm{HCO}^{-}\right)$concentration indicated that $64 \%$ of the wells have the permissible limits of drinking water expect well 5 which record very high value is not suitable for irrigation. Concentration of nutrient $\left(\mathrm{NO}_{3}{ }^{-}\right),\left(\mathrm{NH}_{4}{ }^{+}\right)$ and $\left(\mathrm{PO}_{4}{ }^{3-}\right)$ higher acceptable value due to extensive use of fertilizer and expansion in agriculture work at study area.

Irrigation character of samples based on $\mathrm{SAR}, \mathrm{RSC}, \mathrm{Na} \%$ and $\mathrm{Mg} \%$ indicate that a lot of wells are unsuitable for irrigation. The amount of trace elements in all studied groundwater samples are found below and/or not detected in water samples which specified limit of (WHO) set for drinking purposes.

From this study can concluded that Wadi El-Natrun have higher agriculture work and there are elevation in his communities and to achieve sustainable development must make temporary assessment to his ground water to stand each time to environmental impact for its ground water. 


\section{REFERANCE}

Abd El-Baki, A.A. (1983): Hydrogeological and hydrogeochemical studies on the area west of Rosetta branch and south of El Nasr canal. Ph.D Thesis, Faculty of Science, Ain Shams University, Egypt, pp 156.

Abu Zeid, K.A. (1984): Contribution to the geology of Wadi El-Natrun area and its surroundings. MSc Thesis, Faculty of Science, Cairo University, Egypt, pp. 15-25.

Ahmed, S.A. (1999): Hydrogeological and isotope assessment of groundwater in Wadi el-Natrun and Sadat City, Egypt. Ph.D. thesis, Faculty of Science, Cairo University, Egypt. pp. 237.

Ammar A.I. (2010): "Estimating the Groundwater Storage from the Electrical Resistivity Measurements in Wadi El-Natrun Area, Western Desert, Egypt". Journal of American Science. 6(10), 492-502.

Attia, A.k., Hilmy M.E. and Hagab, O.A. (1970): Mineralogy of the sediments of Wadi El-Natrun Terraces. Desert Institute Bulletin, Cairo, Egypt. 20(2), 327-357.

Cherif, O.H., Kelani, A.H. and Mostafa, A.R. (2006): Stratigraphic lexicon and explanatory notes to the geological map of the north western desert, Egypt. UNESCO, Cairo, pp148.

Dawoud, A.D., Darwish, M.M., El-Kady, M.M., 2005: GIS-based groundwater management model for western Nile Delta. Water Resour. Manage. 19 (5), 585-604.

EL Fayoumy, F.I. (1964). Hydrology of groundwater supplies in Wadi ElNatrun area, MSc Thesis, Faculty of Science, Cairo University, Egypt.pp.109.

El-Maghraby, M.M. (1990): Geographical and hydorological studies of Sadat City, Egypt. M.Sc. Thesis, Fac. Sci., Alex. University, Egypt. PP. 14-45.

El Shazly, E., Abdel Hady, M., El-Gawaby, H., El-Kassas, K., Khawasik, S.M., El-Shazly, M.M. and Sanad, S. (1975): Geologic interpretation of Landsat satellite images for west Nile Delta area. 
Remote Sensing Center \& Academy of Scientific Research and Technology. Cairo, Egypt, pp 38.

Fekry, A.M. (1993): Hydrogeological studies of the southern regions west of the Nile Delta, Ph. D. Thesis, Faculty of Science, Ain Shams University, Cairo, Egypt, pp 121.

FAO, (1985): Water quality for agriculture, FAO irrigation and drainage paper No. 29, Rome.

Gomma, A.M. (1995): Comparative hydrogeological and hydrogeochemical study on some aquifers, west of Nile Delta, Egypt .Ph.D. Thesis, Faculty of Science. Cairo University, Egypt, pp.236.

Gray, N.F. (2005): "Water Technology an Introduction for Environmental Scientists and Engineers'. $2^{\text {nd }}$ Edition, Elsevier Butterworth Henemann, oxford, pp. 535-751.

Hagen, (1987): "Irrigation of agricultural land" Agronomy series, U.S.A, No.11, pp.10-14.

La Moreaux, P.E. (1962): Reconnaissance report and recommendations for groundwater investigations, Wadi El-Natrun, Western Desert of Egypt. Report prepared for the General Desert Development Organization, Cairo, Egypt, pp 56.

Lawson, E. O., (2011): physic-chemical parameters and heavy metal contents of water from the mangrove swamps of Lagos, lagoon, Nigeria. Adv. Biol. Res., 5. 8-21.

Masoud, A.; Atwia, A. M. G. (2011): Spatio-temporal characterization of the Pliocene aquifer conditions in Wadi El-Natrun area, Egypt, Environ Earth Sci (2011) 62:1361-1374.

Meteorological Authority (2006): The normal's for Egypt up to 2007. Ministry of Civil Aviation, Cairo, Egypt. Meteorological Res. Bull., 22: 86- 87.

Murugesan A., Ramu A., and Kannan N., (2006): Water quality assessment from Uthamapalayam municipality in Theni District, Tamil Nadu, India. Pollution Research 25:163-166. 
Omara, S.M. and Sanad, S. (1975): Rock stratigraphy and structural features of the area between Wadi El Natrun and the Moghra Depression, Western Desert Egypt. Geol. Jahrbuch. Schweizerbart'sche Verlagsbuchhandlung, Stuttgart, Reihe B; 16, pp 45-73.

Pavlov, M. (1962): Geology, hydrogeology and groundwater hydrology ofWadi el Natrun and the adjacent areas. In preliminary report part 2 (Ed). Hydrogeology. Desert institute and the general development organization. Cairo, 63 pp.

Qureshimatva U.M., Maurya R.R., Gamit S.B., Patel R.D., and Solanki H.A., (2015): Determination of Physico-Chemical Parameters and Water Quality Index (Wqi) of Chandlodia Lake, Ahmedabad, Gujarat, India Environmental \& Analytical Toxicology.4 (5), 1-6

Rabinove C.J., Longfort R.H. and Brook J.W., (1958): Saline water resource of North Dakota U.S. Geol. Surv. Water supply. paper 1428, p. 72 .

RIGW, (1992): Groundwater Resources and Projection of Groundwater Development, Water Security Project. National Water Research Center, Egypt, pp 37.

REGWA, (1993): The groundwater in a study area southern of Wadi El Farigh. The general company for research and groundwater, Interior report, Cairo, pp 74.

RIGW/IWACO, (1990): Hydrogeological inventory and groundwater development plan, Western Nile Delta region. Main report, vol. 4, Technical Note 77.01300-90-02.RIGW, pp 64.

Sadek, A., Pigott, J., Barakat, M., Abu, El.-Atta A., Sadek, S., (2005): Hydrocarbon evaluation of Natrun basin, West Nile Delta, Egypt. GRMENA, Cairo 1,pp 3-31.

Said, R. (1962). The Geology of Egypt. Elsevier Pub. Co., Amesterdam, New York. pp. 375-378. 
Sharaky, A.M.; Atta, S.A.; El Hassaneinl A.S. and Khallaf, K.M.A. (2007): .hydrogeochemistry of ground water in the western Nile delta 2nd International Conference on the Geology of Tethys, Cairo University, Egypt. pp 19-21.

Shata, A.A. (1962): The Geology, origin and age of the groundwater supplies in some desert areas of U.A.R., Desert Institute Bulletin, Cairo, Egypt, 12: 61-124.

Shata, A.A. and El-Fayoumy, I.F. (1967): Geomorphological and morphopedological aspects of the region west of the Nile Delta with special reference of Wadi El-Natrun area. Desert Institute Bulletin, Cairo, Egypt. (1), 1-28.

Shomar,B., Abu Fakher,S., Yahya,A. (2010): Assessment of Groundwater Quality in the Gaza Strip, Palestine Using GIS Mapping Water Resource and Protection, No., pp 93-104.

Szabolcs I., and Darab C., (1964): The influence of irrigation water of high sodium carbonate content on soils. In I. Szabolics (Ed.), Proc 8th International Congress Soil Science Sodics Soils, Res Inst Soil Sci Agric Chem Hungarian Acad Sci, ISSS Trans II, 1964, 802812.

Todd D. K., (2006): "Groundwater hydrology, Ch.7: Quality of Groundwater", 2nd edition, John Wiley and Sons, Haryana, India, pp.267-315.

US Salinity Laboratory, (1954):'Diagnosis and improvement of saline and alkaline soils", US Dept. of Agriculture Handbook No.60. PP.160.

USEPA (U.S. Environmental Protection Agency), (2005): Drinking water standards, URL: http://www.epa.com/

Vogel, A.I., (1961): Quantitative inorganic analysis, including elementary instrumental analysis. Longmans $3^{\text {rd }}$ Edition London.

Wassef, R.S. (2010): Development of Groundwater flow model for water resources Management at the development area west of the Rosetta branch, Egypt Faculty of Natural Sciences III of the Martin Luther University, Halle-Wittenberg. pp 9-104. 
World Health Organization (WHO), (1996): "Nutrient in Drinking-water" for development of Guidelines for World Health Organization Drinking-water Quality. pp. 40-120.

World Health Organization (WHO), (1998) :( World Health Organization), Copper. Geneva, World Health Organization, International Program on Chemical Safety (Environmental Health Criteria, monograph No. 2000.pp.89-175.

World Health Organization (WHO), (2004): "International standards for drinking water" (2nd edition). World Health Organization, Geneva. Switzerland. pp. 296-409.

World Health Organization (WHO), 2006: Guidelines for Drinking-Water Quality, third ed., vol. 1 - Recommendations, Geneva. pp. 296459.

World Health Organization (WHO), 2011: Guidelines for Drinking-Water Quality, fourth ed., Geneva. pp. 222-230. 


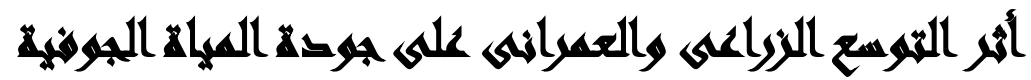

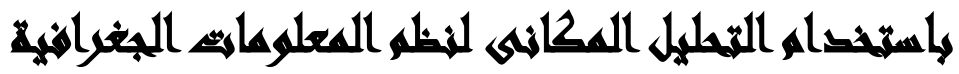

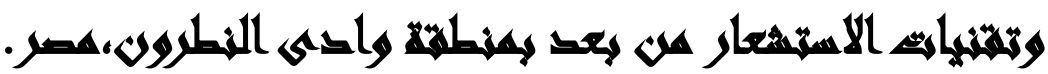

\section{$[r]$}

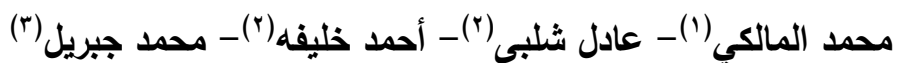

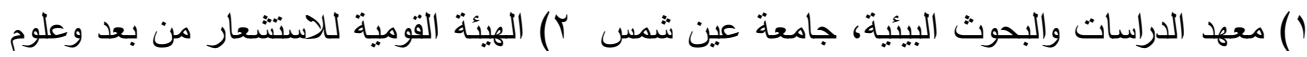

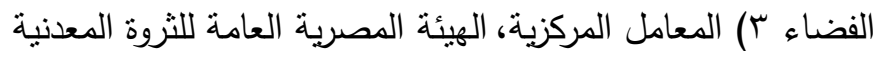

\section{المسرخليس}

تواجه مصر مشكلة حقيقية في ندرة المياه. تتركز المجتمعات الحضرية والزراعية في مصر المرك داخل وادي النيل ودلتاة حيث توجد المياه بكثرة. شجعت الحكومة المصرية المستثمرين والمزارعين

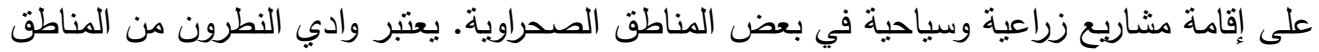

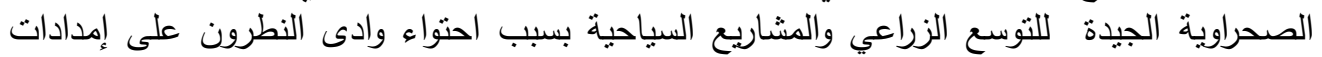

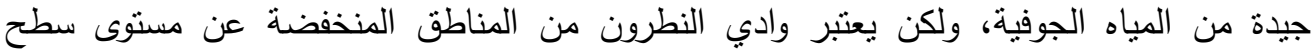
البحروهذا يسبب تسرب المياه الملوثة والمحتويةعلى الاسمدة الكيماوية إلى المياه المياه الجوفية، كذلك الكية

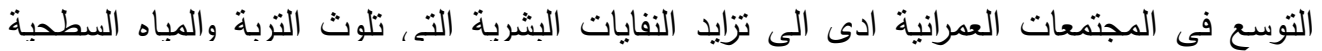

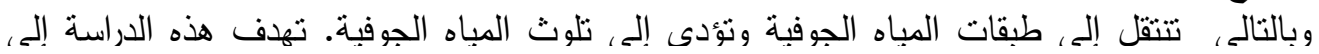

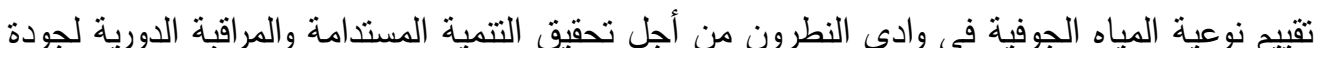

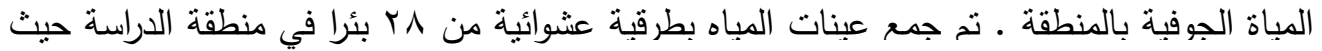

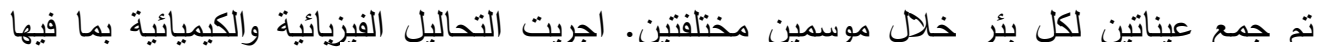

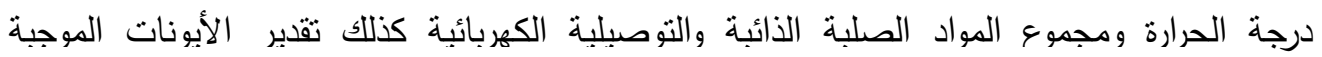

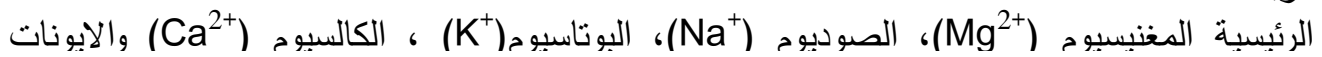

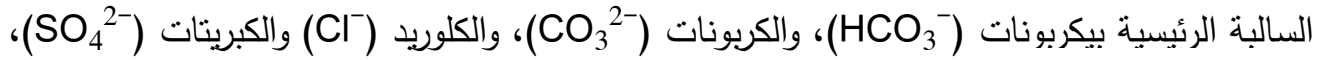

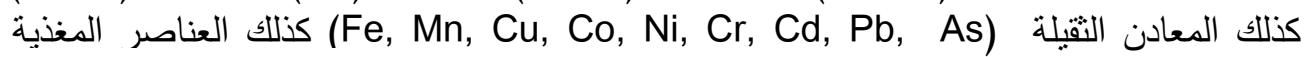

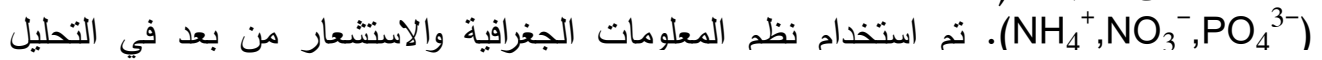

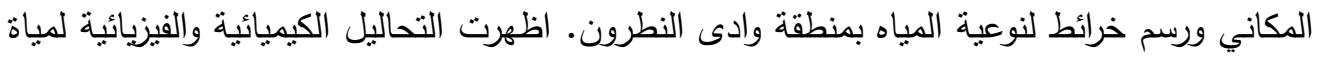

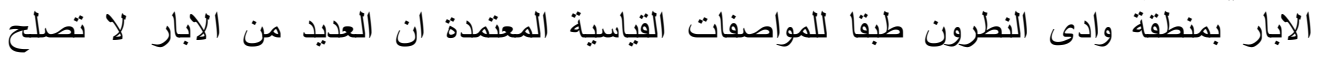

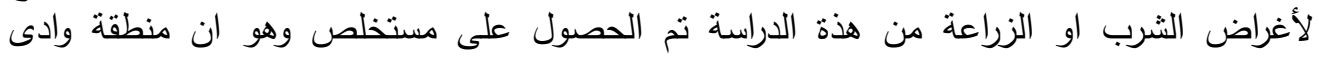
النطرون تتهـ زيادة كبيرة فى التوسع الزراعى والعمرانى ولكى يتم تحقيق التتمية المستدامة يجب ان ان 
J. Environ. Sci.

Institute of Environmental Studies and Research - Ain Shams University

يتم عمل تقييم دورى للمياه الجوفية بالمنطقة للوقوف دائما على مدى التاثير البيئى على المياه الجوفية فى منطقة وادى النطرون.

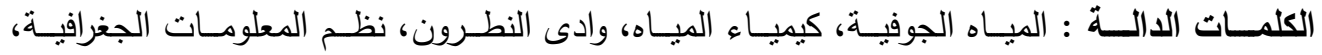
الاستشعارمن بعد، التلوث البيئى. 